\title{
A Comparative Study of the Serum Levels of Follicle Stimulating Hormone (FSH) and Luteinizing Hormone (LH) During Follicular Phase in Secondary and Primary Infertile Women of Reproductive Age
}

\author{
*Arome Solomon Odiba ${ }^{1}$, Parker Elijah Joshua ${ }^{2}$, Chimere Young Ukegbu ${ }^{2}$, \\ Iruoghene Onosakponome ${ }^{2}$ \\ ${ }^{I}$ Department of Biochemistry, University of Jos, Plateau State, Nigeria \\ ${ }^{2}$ Department of Biochemistry, University of Nigeria, Nsukka, Enugu State, Nigeria
}

\begin{abstract}
We compared secondary and primary infertile women of reproductive age in terms of the levels of FSH and LH. This investigation was carried out at the Jos University Teaching Hospital (JUTH), Nigeria. 150 women within the reproductive age of 25-34 years, categorized into control $(n=50)$, secondary infertile $(n=50)$ and primary infertile $(n=50)$ were randomly drawn for the study. A fasting morning blood sample was obtained from the patients during the follicular phase of the cycle for serum FSH and LH investigation by enzyme-linked immunosorbent assay (ELISA) methods. SerumFSH results for secondary infertile groupexpressed as mean $\pm S D$ is $6.07 \pm 2.53$ [t-test value of $0.12(p<0.05)$ when compared with the control], primary infertile group is $10.87 \pm 11.39$, [t-test value of $0.02(p<0.05)$ when compared with the control]. Serum LH results for secondary infertile group expressed as mean $\pm S D$ value is $4.92 \pm 3.54$ [ $t$-test value of $0.02(p<0.05)$ when compared with control], primary infertile is $8.61 \pm 5.76$ [( $t$-test value of $0.01 \quad(p<0.05)$ when compared with control].In the secondary infertile group, $2 \%$ had FSH serum levels below, $92 \%$ within and $6 \%$ above the normal range limits. For $\mathrm{LH}, 2 \%$ have serum levels below, $90 \%$ within and $8 \%$ above normal range limits. In the primary infertile group, $18 \%$ have FSH levels below, $46 \%$ within, and $36 \%$ above the normal range limits. For LH, $4 \%$ have levels below, 56\% within, 40\% above the normal range limits.Proportionality investigation between FSH and LH levels shows a direct proportionality. There is no significant difference between secondary infertile group and the control group, but there is a significant difference between the primary infertile group and the control in terms of FSH and LH levels. Proportionality investigation suggests a direct proportionality between FSH and $L H$.
\end{abstract}

Keywords: Hormone, infertility, ovulation, primary, secondary

\section{Introduction}

Infertility primarily refers to the inability of an individual to contribute to conception for at least one year of unprotected intercourse without using any contraceptives [1]. It has been observed globally that 10-15\% of couples within the reproductive age limits are infertile and the prevalence varies from country to country. Female Infertility has two types: primary infertility; a term used for a woman who has never achieved a pregnancy. Secondary infertility refersto the state of a woman who has previously succeeded in achieving at least one pregnancy but unable to conceive again or face poor pregnancy outcomes such as abortions or stillbirths [2]. However, there is a common trend of secondary infertility outnumbering primary infertility across all the developing countries [3]. The major causes are postabortal, puerperal and reproductive tract infections (RTIs) [4]. Infertility has been viewed to be associated with increased psychological distress for the couples, with greater social pressures for women than men [5],[6]. This is more marked for women with secondary infertility. Studies have shown that in these situations women not only are harassed by the family members but, face various forms of marital instabilities too [8]. Amongst the many factors that account for secondary and primary infertility in women are the quantitative hormonal abnormalities in Follicle Stimulating Hormone (FSH) and luteinizing hormone (LH).

FSH is a key hormone of mammalian reproduction that is necessary for gonadal development and maturation at puberty and for gamete production during the reproductive phase of life [9]. FSH is a member of the glycoprotein hormone family that also includes LH, HCG, and TSH. Follicle-stimulating hormone (FSH) is critical for ovarian folliculogenesis in female fertility. FSH plays a key role in antral follicle development and, in combination with luteinizing hormone (LH), stimulates preovulatory follicular growth [10]. In females, an acute rise of LH ("LH surge") triggers ovulation[10] and development of the corpus luteum. The pituitary gland secretes FSH and(LH) in a pulsatile manner in response to gonadotropin releasing hormone (GnRH). Most of the information available concerning the fluctuations of follicle-stimulating hormone and Luteinizing hormone 
in human subjects has been gained through bioassay of serum. This present investigation evaluates and compares the hormonal profile of secondary and primary infertile women of reproductive age. The aim of the study was to estimate and compare the mean value of FSH and LH serum levels in secondary and primary infertile women as compared to the control group as well as the physiological correlation between FSH and LH levels.

\subsection{Study Subjects}

\section{Procedure For Research}

This investigation was carried out at the Jos University Teaching Hospital, University of Jos, Nigeria. The is made up of 150 women of reproductive age, categorized into control $(n=50)$, secondary infertile $(n=50)$ primary infertile $(n=50)$ certified as secondary and primary infertile respectively by a gynecologist and referred for infertility investigation. The inclusion criteria for the selection of cases were diagnosis of secondary and primary infertility, age between 25-34 years and duration of marriage more than one year. The exclusion criteria that were adopted during case selection were male factor infertility and amongst the female factors were tubal factor, any congenital anomaly of the urogenital tract, or any obvious organic lesion [2]. The group of infertile women consisted of patient with menstrual cycle lasting between 28-30 days and with ovulation period between the $12^{\text {th }}$ and $16^{\text {th }}$ day of the cycle.

\subsection{Collection of Sample}

A fasting morning blood sample was obtained from each of the patients during the follicular phase of the cycle by venipuncture between day 5 and 10 of the menstrual cycle, into a plain redtop venipuncture tube without additives or anti-coagulants and allowed to clot.

\subsection{Procedure}

The blood was allowed to clot and the serum was decanted for analysis of the biochemical parameter. Hemolysis sera were discarded and a fresh specimen was obtained. The serum was stored between $2-8^{\circ} \mathrm{C}$ and assays were completed within three days. FSH and LH serum levels were estimated by Immuno enzymatic assay by ELISA Reader. The kits were obtained from Fortress Diagnostic Limited, United Kingdom, Northern Ireland [11].

\subsection{Biochemical parameters}

Each of the samples was investigated for serum levels of FSH and LH.

\subsection{Statistical Analysis}

The descriptive characteristics of the group variables were expressed as mean values and standard deviation. Comparison of the Mean values between the groups was done usingunpaired t-test. Significance level was taken as $\mathrm{P}<0.05$. Statistical analysis was done using IBM SPSS version 20 package and MS-excel.

\section{Experimental Results And Discussion}

\subsection{Results}

Table 1.Serum levels of FSH and LH for secondary infertile women group

\begin{tabular}{|c|c|c|c|c|}
\hline Patient I.D & $\begin{array}{l}\text { FOLLICULAR PHASE SERUM } \\
\text { FSH LEVEL }(\mathrm{ml} \mu / \mathrm{L})\end{array}$ & R.INF & $\begin{array}{l}\text { FOLLICULAR PHASE SERUM LH LEVEL } \\
(\mathrm{ml} \mu / \mathrm{L})\end{array}$ & R.INF \\
\hline 01 & 4.5 & $\mathrm{~W}$ & 2.2 & $\mathrm{~W}$ \\
\hline 02 & 4.4 & $\mathrm{~W}$ & 8.7 & $\mathrm{~W}$ \\
\hline 03 & 3.1 & $\mathrm{~W}$ & 2.4 & $\mathrm{~W}$ \\
\hline 04 & 3.5 & $\mathrm{~W}$ & 2.7 & $\mathrm{~W}$ \\
\hline 05 & 6.1 & $\mathrm{~W}$ & 8.4 & $\mathrm{~W}$ \\
\hline 06 & 3.8 & $\mathrm{~W}$ & 2.1 & $\mathrm{~W}$ \\
\hline 07 & 4.8 & $\mathrm{~W}$ & 4.9 & $\mathrm{~W}$ \\
\hline 08 & 6.4 & $\mathrm{~W}$ & 5.9 & $\mathrm{~W}$ \\
\hline 09 & 4.8 & $\mathrm{~W}$ & 12.7 & A \\
\hline 10 & 6.0 & $\mathrm{~W}$ & 2.1 & $\mathrm{~W}$ \\
\hline 11 & 3.5 & $\mathrm{~W}$ & 5.3 & $\mathrm{~W}$ \\
\hline 12 & 6.3 & $\mathrm{~W}$ & 4.6 & $\mathrm{~W}$ \\
\hline 13 & 4.6 & $\mathrm{~W}$ & 0.9 & $\mathrm{~W}$ \\
\hline 14 & 5.4 & $\mathrm{~W}$ & 0.8 & $\mathrm{~W}$ \\
\hline 15 & 3.5 & $\mathrm{~W}$ & 2.1 & $\mathrm{~W}$ \\
\hline 16 & 7.5 & $\mathrm{~W}$ & 4.2 & $\mathrm{~W}$ \\
\hline 17 & 8.9 & $\mathrm{~W}$ & 0.7 & $\mathrm{~W}$ \\
\hline 18 & 5.5 & $\mathrm{~W}$ & 9.8 & W \\
\hline 19 & 13.1 & $\mathrm{~A}$ & 11.8 & $\mathrm{~A}$ \\
\hline
\end{tabular}


A Comparative Study of the Serum Levels of Follicle Stimulating Hormone (FSH) and Luteinizing

\begin{tabular}{|c|c|c|c|c|}
\hline 20 & 5.6 & W & 8.4 & $\mathrm{~W}$ \\
\hline 21 & 4.4 & $\mathrm{~W}$ & 4.3 & $\mathrm{~W}$ \\
\hline 22 & 8.1 & $\mathrm{~W}$ & 1.5 & $\mathrm{~W}$ \\
\hline 23 & 12.4 & A & 12.5 & A \\
\hline 25 & 6.2 & $\mathrm{~W}$ & 8.5 & $\mathrm{~W}$ \\
\hline 26 & 5.4 & $\mathrm{~W}$ & 5.7 & $\mathrm{~W}$ \\
\hline 27 & 5.0 & $\mathrm{~W}$ & 2.3 & $\overline{\mathrm{W}}$ \\
\hline 29 & 2.8 & B & 0.2 & B \\
\hline 30 & 7.4 & $\mathrm{~W}$ & 0.6 & $\mathrm{~W}$ \\
\hline 31 & 8.6 & W & 0.5 & W \\
\hline 32 & 5.3 & W & 4.3 & $\mathrm{~W}$ \\
\hline 33 & 4.7 & $\mathrm{~W}$ & 1.3 & $\mathrm{~W}$ \\
\hline 34 & 3.6 & $\mathrm{~W}$ & 1.3 & $\mathrm{~W}$ \\
\hline 38 & 5.7 & W & 2.4 & $\mathrm{~W}$ \\
\hline 39 & 6.8 & $\mathrm{~W}$ & 6.9 & $\mathrm{~W}$ \\
\hline 40 & 4.3 & $\mathrm{~W}$ & 9.9 & $\mathrm{~W}$ \\
\hline 41 & 6.7 & $\mathrm{~W}$ & 4.3 & $\mathrm{~W}$ \\
\hline 42 & 13.4 & $\mathrm{~A}$ & 12.8 & A \\
\hline 43 & 4.6 & $\mathrm{~W}$ & 8.7 & $\mathrm{~W}$ \\
\hline 44 & 3.4 & $\mathrm{~W}$ & 2.3 & $\bar{W}$ \\
\hline 45 & 5.6 & W & 8.4 & W \\
\hline 46 & 9.7 & $\mathrm{~W}$ & 6.3 & $\mathrm{~W}$ \\
\hline 47 & 9.4 & $\mathrm{~W}$ & 7.8 & $\mathrm{~W}$ \\
\hline 48 & 9.7 & $\mathrm{~W}$ & 3.4 & $\mathrm{~W}$ \\
\hline
\end{tabular}

Table 2. Serum levels of FSH and LH for primary infertile women group

\begin{tabular}{|c|c|c|c|c|}
\hline $\begin{array}{l}\text { Patient I.D } \\
\text { number }\end{array}$ & $\begin{array}{l}\text { FOLLICULAR PHASE SERUM } \\
\text { FSH LEVEL }(\mathrm{ml} \mu / \mathrm{L})\end{array}$ & R.INF & $\begin{array}{l}\text { FOLLICULAR PHASE SERUM } \\
\text { LH LEVEL }(\mathrm{ml} \mu / \mathrm{L})\end{array}$ & R.INF \\
\hline 01 & 14.3 & $\mathrm{~A}$ & 3.9 & $\mathrm{~W}$ \\
\hline 02 & 16.5 & $\mathrm{~A}$ & 5.8 & $\mathrm{~W}$ \\
\hline 03 & 9.8 & $\mathrm{~W}$ & 4.0 & $\mathrm{~W}$ \\
\hline 04 & 10.3 & W & 0.8 & W \\
\hline 05 & 12.8 & $\mathrm{~A}$ & 1.2 & $\mathrm{~W}$ \\
\hline 06 & 3.4 & $\mathrm{~W}$ & 1.2 & $\mathrm{~W}$ \\
\hline 07 & 6.8 & $\mathrm{~W}$ & 17.8 & $\mathrm{~A}$ \\
\hline 08 & 9.9 & $\mathrm{~W}$ & 12.0 & A \\
\hline 09 & 13.8 & $\mathrm{~A}$ & 16.3 & A \\
\hline 10 & 5.2 & W & 6.9 & W \\
\hline 11 & 73.9 & A & 18.0 & A \\
\hline 12 & 13.0 & $\mathrm{~A}$ & 6.2 & $\mathrm{~W}$ \\
\hline 13 & 15.5 & $\mathrm{~A}$ & 13.9 & $\mathrm{~A}$ \\
\hline 14 & 7.2 & $\mathrm{~W}$ & 9.4 & $\mathrm{~W}$ \\
\hline 15 & 14.2 & $\mathrm{~A}$ & 20.1 & $\mathrm{~A}$ \\
\hline 16 & 28.1 & $\mathrm{~A}$ & 19.3 & $\mathrm{~A}$ \\
\hline 17 & 3.3 & W & 9.4 & W \\
\hline 18 & 2.7 & $\mathrm{~B}$ & 3.7 & $\mathrm{~W}$ \\
\hline 19 & 1.4 & $\mathrm{~B}$ & 2.6 & $\mathrm{~W}$ \\
\hline 20 & 8.5 & W & 4.5 & $\mathrm{~W}$ \\
\hline 21 & 11.4 & $\mathrm{~W}$ & 12.5 & A \\
\hline 22 & 7.0 & $\mathrm{~W}$ & $\begin{array}{l}5.8 \\
\end{array}$ & $\mathrm{~W}$ \\
\hline 23 & 2.3 & B & 11.7 & A \\
\hline 24 & 2.7 & B & 12.3 & A \\
\hline 25 & 16.6 & $\mathrm{~A}$ & 7.5 & $\mathrm{~W}$ \\
\hline 26 & 17.4 & A & 12.2 & A \\
\hline 27 & 2.5 & $\mathrm{~B}$ & 4.1 & $\mathrm{~W}$ \\
\hline 28 & 36.5 & A & 20.9 & $\mathrm{~A}$ \\
\hline 29 & 6.4 & $\mathrm{~W}$ & 7.1 & $\mathrm{~W}$ \\
\hline 30 & 1.0 & B & 0.1 & B \\
\hline 31 & 7.1 & $\mathrm{~W}$ & 8.1 & $\mathrm{~W}$ \\
\hline 32 & 20.4 & $\mathrm{~A}$ & 15.4 & $\mathrm{~A}$ \\
\hline 33 & 9.0 & W & 8.0 & W \\
\hline 34 & 11.8 & $\mathrm{~W}$ & 14.8 & $\mathrm{~A}$ \\
\hline
\end{tabular}




\begin{tabular}{|c|c|c|c|c|}
\hline 35 & 5.8 & $\mathrm{~W}$ & 5.7 & $\mathrm{~W}$ \\
\hline 36 & 6.3 & $\mathrm{~W}$ & 1.5 & $\mathrm{~W}$ \\
\hline 37 & 5.3 & W & 5.5 & W \\
\hline 38 & 13.0 & A & 6.3 & W \\
\hline 39 & 7.9 & $\mathrm{~W}$ & 0.4 & B \\
\hline 40 & 14.0 & A & 11.9 & A \\
\hline 41 & 2.7 & B & 8.8 & $\mathrm{~W}$ \\
\hline 42 & 12.3 & A & 14.9 & A \\
\hline 43 & 4.5 & $\mathrm{~W}$ & 3.2 & $\mathrm{~W}$ \\
\hline 44 & 6.9 & W & 12.3 & A \\
\hline 45 & 1.9 & B & 2.1 & $\mathrm{~W}$ \\
\hline 46 & 7.8 & $\mathrm{~W}$ & 4.2 & W \\
\hline 47 & 2.1 & B & 16.1 & A \\
\hline 48 & 14.1 & $\mathrm{~A}$ & 10.9 & A \\
\hline 49 & 3.3 & $\mathrm{~W}$ & 7.3 & $\mathrm{~W}$ \\
\hline 50 & 12.9 & $\mathrm{~A}$ & 1.9 & A \\
\hline
\end{tabular}

Table 3. FP Serum levels of FSH and LH for control group

\begin{tabular}{|c|c|c|c|c|}
\hline $\begin{array}{l}\text { Patient(control) } \\
\text { I.D }\end{array}$ & $\begin{array}{l}\text { FOLLICULAR PHASE } \\
\text { SERUM FSH LEVEL }(\mathrm{ml} \mu / \mathrm{L})\end{array}$ & R.INF & $\begin{array}{l}\text { FOLLICULAR PHASE SERUM LH LEVEL } \\
(\mathrm{ml} \mu / \mathrm{L})\end{array}$ & R.INF \\
\hline 01 & 6.4 & $\mathrm{~W}$ & 0.4 & $\mathrm{~B}$ \\
\hline 02 & 8.3 & $\mathrm{~W}$ & 0.9 & $\mathrm{~W}$ \\
\hline 03 & 12.3 & A & 10.0 & $\mathrm{~W}$ \\
\hline 04 & 5.8 & $\mathrm{~W}$ & 0.7 & $\mathrm{~W}$ \\
\hline 05 & 3.6 & $\mathrm{~W}$ & 1.8 & $\mathrm{~W}$ \\
\hline 06 & 9.5 & $\mathrm{~W}$ & 7.2 & $\mathrm{~W}$ \\
\hline 07 & 4.0 & $\mathrm{~W}$ & 10.8 & A \\
\hline 08 & 4.8 & $\mathrm{~W}$ & 10.5 & $\mathrm{~W}$ \\
\hline 09 & 12.4 & A & 4.4 & $\mathrm{~W}$ \\
\hline 10 & 9.9 & W & 6.5 & W \\
\hline 11 & 3.1 & W & 13.2 & A \\
\hline 12 & 3.3 & $\mathrm{~W}$ & 7.8 & $\mathrm{~W}$ \\
\hline 13 & 8.5 & $\mathrm{~W}$ & 6.3 & $\mathrm{~W}$ \\
\hline 14 & 2.9 & $\mathrm{~B}$ & 9.1 & $\mathrm{~W}$ \\
\hline 15 & 8.3 & $\mathrm{~W}$ & 12.0 & $\mathrm{~A}$ \\
\hline 16 & 10 & $\mathrm{~W}$ & 9.9 & $\mathrm{~W}$ \\
\hline 17 & 3.1 & W & 0.7 & $\mathrm{~W}$ \\
\hline 18 & 2.4 & B & 3.9 & $\mathrm{~W}$ \\
\hline 19 & 4.4 & W & 0.5 & $\mathrm{~W}$ \\
\hline 20 & 8.9 & $\mathrm{~W}$ & 0.9 & $\mathrm{~W}$ \\
\hline 21 & 12.3 & $\mathrm{~A}$ & 3.7 & $\mathrm{~W}$ \\
\hline 22 & 8.4 & $\mathrm{~W}$ & 2.7 & $\mathrm{~W}$ \\
\hline 23 & 3.9 & $\mathrm{~W}$ & 10.4 & $\mathrm{~W}$ \\
\hline 24 & 8.2 & $\mathrm{~W}$ & 7.3 & $\mathrm{~W}$ \\
\hline 25 & 8.9 & $\mathrm{~W}$ & 4.5 & $\mathrm{~W}$ \\
\hline 26 & 10.1 & $\mathrm{~W}$ & 2.2 & $\mathrm{~W}$ \\
\hline 27 & 8.3 & $\mathrm{~W}$ & 6.1 & $\mathrm{~W}$ \\
\hline 28 & 5.5 & $\mathrm{~W}$ & 11.9 & $\mathrm{~A}$ \\
\hline 29 & 2.9 & B & 8.1 & $\mathrm{~W}$ \\
\hline 30 & 9.0 & $\mathrm{~W}$ & 0.1 & B \\
\hline 31 & 10.1 & $\mathrm{~W}$ & 9.8 & $\mathrm{~W}$ \\
\hline 32 & 10.4 & $\mathrm{~W}$ & 11.4 & A \\
\hline 33 & 8.2 & $\mathrm{~W}$ & 8.0 & W \\
\hline 34 & 3.8 & $\mathrm{~W}$ & 7.3 & $\mathrm{~W}$ \\
\hline 35 & 5.9 & $\mathrm{~W}$ & 6.9 & $\mathrm{~W}$ \\
\hline 36 & 4.8 & $\mathrm{~W}$ & 0.9 & $\mathrm{~W}$ \\
\hline 37 & 3.6 & $\mathrm{~W}$ & 2.1 & $\mathrm{~W}$ \\
\hline 38 & 4.7 & $\mathrm{~W}$ & 2.6 & $\mathrm{~W}$ \\
\hline 39 & 8.4 & W & 7.7 & $\mathrm{~W}$ \\
\hline 40 & 5.4 & $\mathrm{~W}$ & 4.6 & $\mathrm{~W}$ \\
\hline 41 & 5.3 & $\mathrm{~W}$ & 9.3 & $\mathrm{~W}$ \\
\hline 42 & 9.5 & $\mathrm{~W}$ & 5.3 & $\mathrm{~W}$ \\
\hline 43 & 11.9 & $\mathrm{~W}$ & 0.3 & B \\
\hline 44 & 2.9 & $\mathrm{~B}$ & 3.5 & $\mathrm{~W}$ \\
\hline 45 & 4.8 & $\mathrm{~W}$ & 7.7 & $\mathrm{~W}$ \\
\hline 46 & 5.9 & $\mathrm{~W}$ & 4.0 & $\mathrm{~W}$ \\
\hline 47 & 12.5 & A & 3.2 & $\mathrm{~W}$ \\
\hline 48 & 3.7 & $\mathrm{~W}$ & 11.8 & A \\
\hline 49 & 7.3 & $\mathrm{~W}$ & 9.1 & $\mathrm{~W}$ \\
\hline 50 & 8.2 & $\mathrm{~W}$ & 3.6 & $\mathrm{~W}$ \\
\hline
\end{tabular}


$\mathbf{R . I N F}=$ Range inference, $\mathbf{B}=$ below normal range, $\mathbf{W}=$ within normal range, $\mathbf{A}=$ above normal range

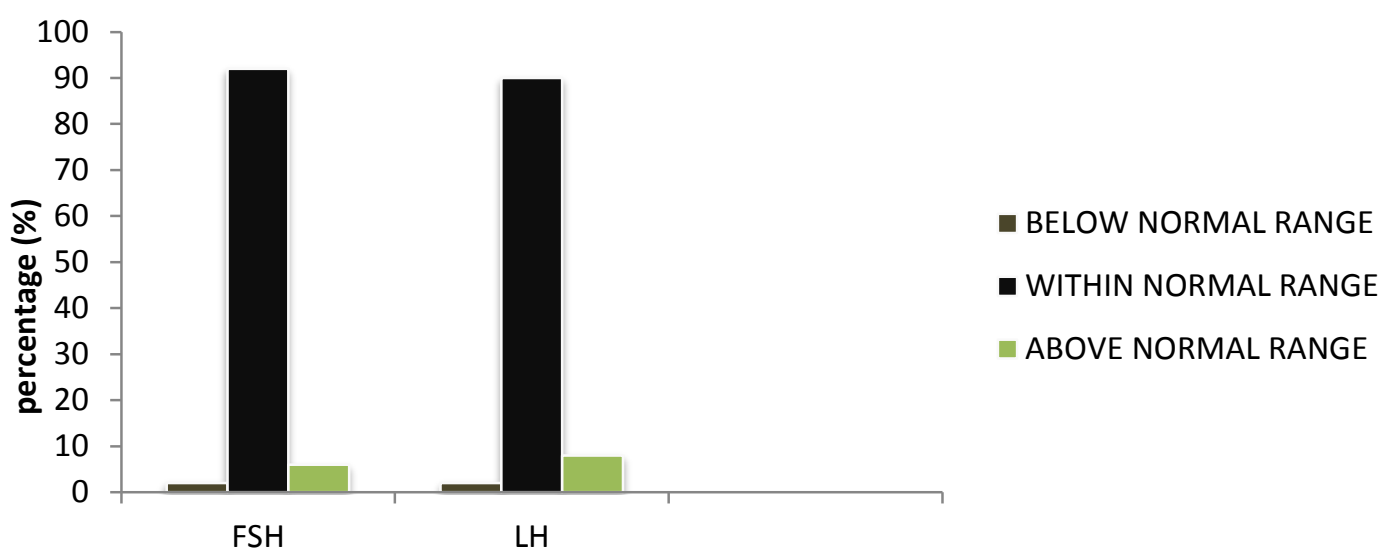

Figure 1: Percentage occurrence of the different categories for secondary infertile group

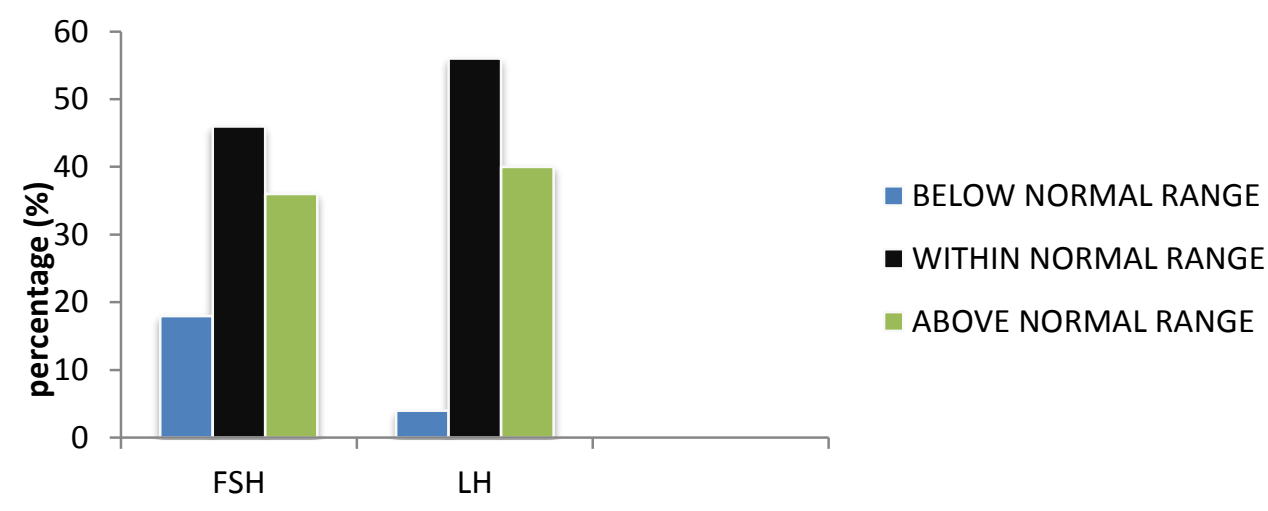

Figure 2: Percentage occurrence of the different categories for primary infertile group

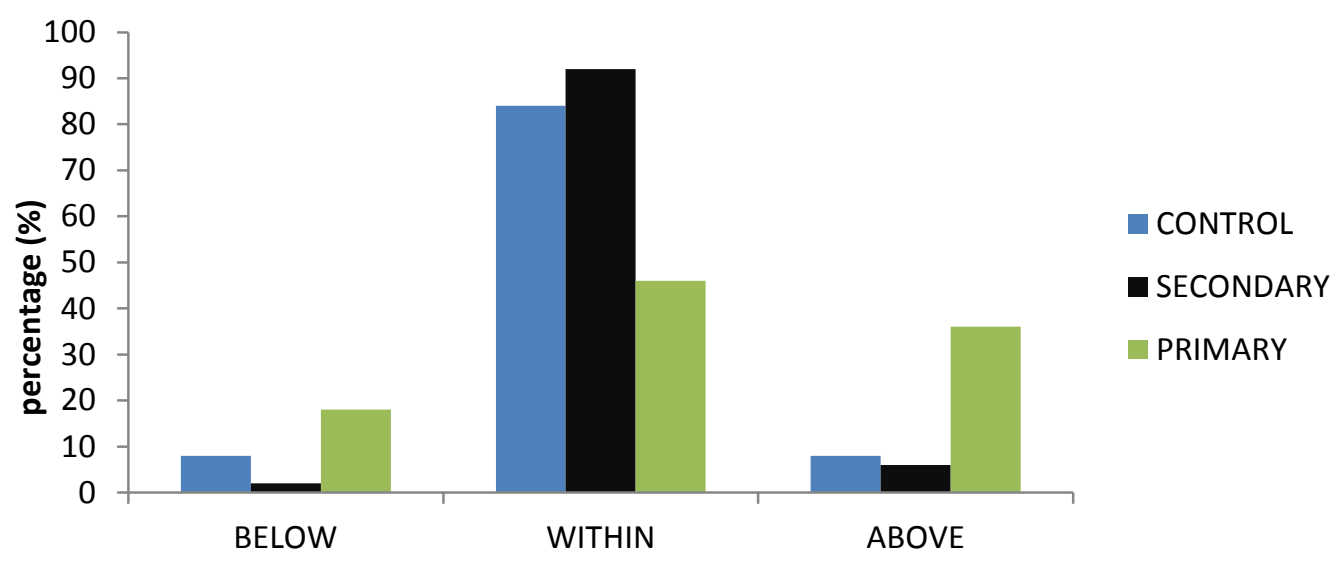

Figure 3: Comparison between the percentage occurrences of the different categories in Control, Secondary and Primary infertile groups for FSH serum levels 


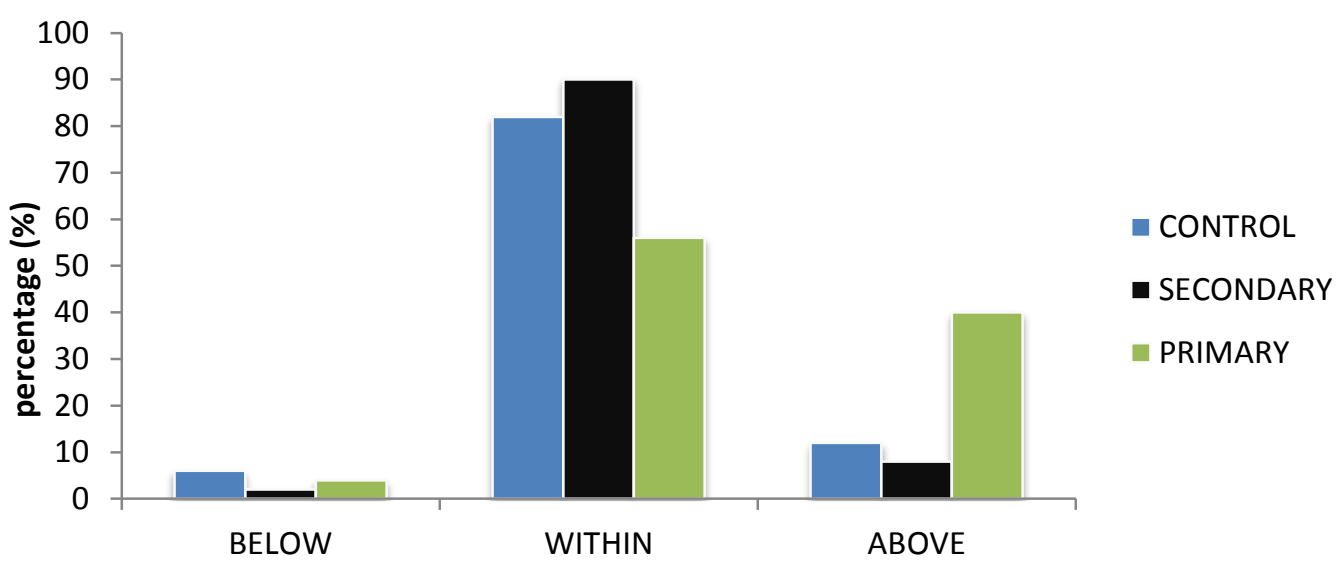

Figure 4: Comparison between the percentage occurrences of the different categories in Control, Secondary and Primary infertile groups for LH serum levels

Table 4: Hormonal characteristics of control and infertile group

\begin{tabular}{lllllll}
\hline Parameters & $\begin{array}{l}\text { Control group } \\
\mathrm{n}=50\end{array}$ & $\begin{array}{l}\text { Secondary Infertile group } \\
\mathrm{n}=50\end{array}$ & t-test value & Primary infertile group & T test value & p-value \\
\hline FSH & $6.93 \pm 3.01$ & $6.07 \pm 2.53$ & 0.12 & $10.87 \pm 11.39$ & 0.02 & 0.05 \\
LH & $5.87 \pm 3.83$ & $4.91 \pm 3.54$ & 0.20 & $8.61 \pm 5.76$ & 0.01 & 0.05 \\
\hline
\end{tabular}

\section{Discussion}

As shown in TABLE 4, SerumFSH results for secondary infertile groupexpressed as mean $\pm \mathrm{SD}$ is $6.07 \pm 2.53$ [t-test value of $0.12(\mathrm{p}<0.05)$ when compared with the control], primary infertile group is $10.87 \pm 11.39$, [t-test value of $0.02(\mathrm{p}<0.05)$ when compared with the control]. Serum LH results for secondary infertile group expressed as mean $\pm \mathrm{SD}$ value is $4.92 \pm 3.54$ [t-test value of $0.02(\mathrm{p}<0.05)$ when compared with control], primary infertile is $8.61 \pm 5.76$ [(t-test value of $0.01(\mathrm{p}<0.05)$ when compared with control].In the secondary infertile group, $2 \%$ had FSH serum levels below, $92 \%$ within and $6 \%$ above the normal range limits as shown in fig. 1. For LH, $2 \%$ have serum levels below, $90 \%$ within and $8 \%$ above normal range limits as shown in fig. 1. In the primary infertile group, $18 \%$ have FSH levels below, $46 \%$ within, and $36 \%$ above the normal range limits (fig. 2). For LH, $4 \%$ have levels below, $56 \%$ within, $40 \%$ above the normal range limits as shown in fig. 2.

A serum level below the normal range limits for FSH $(3.0-12.0 \mathrm{mI} \mu / \mathrm{L})$ and $\mathrm{LH}(0.5-10.5 \mathrm{mI} \mu / \mathrm{L})$ during the follicular phase (TABLE 1 and 2) indicates that the factors causing infertility could be defects in the pituitary gland, GnRH or the hypothalamus [12]. On the other hand, FSH and LH values above the normal limits suggests a problem arising from other components of the reproductive system, probably a defect in the negative feedback regulation mechanism in the hypothalamus by estrogen and progesterone [13]. In this study we found no statistically significant difference in serum FSH and LH levels in the secondary infertile group when compared with the control group and a statistically significant high levels of FSH and LH in the primary infertile group than in the in the control group. Contrary to the result of[14] and [15], both of which reported lower levels of serum FSH and LH in primary infertile women, this present study reports statistically significant higher level of FSH and LH in the primary infertile group. The observed difference between these studies could be as a result of the location of study or the phase of the menstrual cycle. There may be an aberration at the hypothalamus or pituitary (hypogonadotropic-hypogonadism) which resulted in increased levelsof serum FSH and LH in the primary infertile group and leads to infertility. A defect in the negative feedback of estrogen on LH, could lead to increased serum LH and FSH values [16]. Fig. 1 and fig. 2 show a common pattern between FSH and LH levels, having values within (W) the normal range limits recording the highest frequency, values above (A) normal limits ranking second in frequency and values below (B) normal limits being the lowest. This result suggests a physiological correlation between FSH and LH as shown by the direct proportionality in the results. This indicates that any cause of infertility arising from abnormal serum levels of FSH and LH may be due to a factor that has effect on or regulate the functions of these two hormones. This suggests that the abnormality could be associated with GnRH, which controls both FSH and LH production, the pituitary gland which is responsible for the production of FSH and LH, and the hypothalamus which is the control center for GnRH[17]. Cases when FSH and LH serum levels are within the normal limits suggests that the cause of infertility is due to other factors such as damage to the ovary, viral infection, chemotherapy, drugs, and other hormonal abnormalities with estrogen and progesterone that are responsible for development of the endometrium and also unexplained infertility could be the factor [18]. Possibilities of luteal phase defects cannot 
be ruled out even if the serum levels of the two hormones appear to be within normal limits in the follicular phase. According to [19], 65.5\% of infertile women with proper menstrual cycles suffered from luteal phase defect. Hyperprolactinemia could also be a dominant cause of infertility in females and the incidence of hyperprolactinemia was reported to be $42.9 \%$ by [14], $25 \%$ by [20].[21]states that women with higher values of prolactin and luteal phase defects have lower serum levels of FSH, and LH during their menstrual cycle. In Fig. 3, Cases where both FSH and LH serum levels are low (2.9\%) suggests cause of infertility to be due to a defect in the negative feedback of estrogen and progesterone on GnRH[22].

Estrogen and progesterone serum levels should be investigated to ascertain the status of feedback inhibition on GnRH production in infertile women. Magnetic resonance imaging (MRI) should be an additional investigative procedure to completely diagnose cause of infertility as this will detect pituitary tumors that could be responsible for hormonal defects. It could be concluded on the physiological correlation between FSH and $\mathrm{LH}$, as evident in the direct proportionality in the trends of result that, in cases where the two hormones express the same pattern of behavior, the factor responsible for infertility is a factor that controls or has a direct influence the production and function of these two gonadotropins. This then suggest GnRH, pituitaryhypothalamic defects.

\section{Acknowledgment}

The authors would like to thanks to University of Jos teaching Hospital (JUTH), for technical support and making patients available for the successful completion of this research work.

\section{References}

[1] World Health Organization, Challenges in reproductive health research, Biennial Report 1992-1993, WHO, Geneva, Switzerland, 1994.

[2] U. Larsen, G. Masenga, and J. Mlay, Infertility in a community and clinic-based sample of couples in Moshi, northern Tanzania,East African Medical Journal, 83, 2006, 10-17.

[3] World Health Organization, Infertility: atabulation of available data on prevalence of primary and secondary infertility,Geneva Program on Maternal and Child Health and Family Planning. Division of Family Health, 1991.

[4] T. Strahan, Detrimental effects of abortion: an annotated bibliography with commentary(Chicago USA, Springfield, Acorn Books, 2002).

[5] E.K. Herz, Infertility and bioethical issues of the new reproductive technologies, The Psychiatric Clinics of North America, 12(1), 1989, 117-131.

[6] C. Jordan, and T. A. Revenson, Gender differences in coping with infertility: A meta-analysis,Journal of Behavioral Medicine, 22(4), 1999, 341-358.

[7] J. J. Shireen, Infertility in India-levels, patterns and consequences: priorities for social research. Journal of Family Welfare, 44, $1998,15-24$.

[8] N. Sami, and T. S. Ali,Psycho-social consequences of secondary infertility in Karachi,Journal of the Pakistan Medical Association, 56(1), 2006, 19-22.

[9] I. T. Huhtaniemi, and A. P. Themmen, Mutations in human gonadotropin and gonadotropin-receptor genes,Endocrine, 26, 2005, 207-217.

[10] E. A. McGee, and A. J. Hsueh, Initial and cyclic recruitment of ovarian follicles, Endocrine Reviews, 21, 2000, 200-214.

[11] W. D. Odell, and A. F. Parlow,Estimation of FSH test assay. Journal of ClinicalInvestigation, 47, 1981, $25-51$.

[12] S. Nussey, and S. Whitehead,Endocrinology: An Integrated Approach(Oxford: BIOS Scientific Publishers, 2001).

[13] H. A. David, P. Vasantha, and A. D. Daniel,Contributions of androgen and estrogen to fetal programming of ovarian dysfunction.Reproductive Biology and Endocrinology, 4, 2006, 17.

[14] K. Mohan, and S. Mazher, Follicle stimulating hormone, luteinizing hormone and prolactin levels in infertile women in North Chennai, Tamilnadu.Journal of Biological science Research, 1(4), 2010, 279-284.

[15] K. Z. Ryu, B. Z. Byoun, and K. J. Kim, Patterns of circulating gonadotropins (LH and FSH), prolacting and Ovarian steroids (estradiol and progesterone) during the menstrual cycle in Korean women, Yonsei Medical journal, 20, 1979, 2

[16] A. Z. Mohammed, Correlation of prolactin and thyroid hormone concentration with menstrual patterns in infertile women, Annals of African Medicine, 4, 2000, 3.

[17] A. Nemeskéri, A. Detta, and R. N. Clayton, Hypothalamic GnRH and pituitary gonadotroph relationships during rat fetal life,Experimental Clinical Endocrinology, 88(3), 1986, 275-284.

[18] Z. Roupa, M. Polikandrioti,P. Sotiropoulou, E. Faros, A. Koulouri, and M. Gourni, Causes of infertility in women at reproductive age,Health Science Journal, 3(2), 2009, 80-87.

[19] L. Moltz, F. Leidenberger, and C. Weise,Rational hormone diagnosis in normocyclic functional sterility,Journalof Infertility, 51(9), 1991, 756-768.

[20] R. Mishra, R. Baveja, and V. Gupta, Prolactin level in infertility with menstrual irregularities, The Journal ofObstetrics and Gynecology In India, 52, 2002, 40-43.

[21] B. Goswami, S. Patel, and A. Saxena,Correlation of Prolactin and Thyroid Hormone Concentration with Menstrual Patterns in Infertile Women,Journal of Reproductive Infertility 10 (3), 2009, 207-212

[22] P. Bouchard, J. P. and Wolf,S. Hajri, Inhibition of ovulation: comparison between the mechanism of action of steroids and GnRH analogues,Human Reproduction,3(4), 1988, 503-506. 